\title{
KOREAN ECONOMISTS' BELIEF ABOUT ECONOMIC ISSUES
}

\author{
JAE HO $\mathrm{CHO}^{*}$
}

This study compares the degree of consensus and dissension concerning 29 economic propositions among academic and non-academic economists in Korea. This study is based upon an anonymous questionnaire survey of 167 academic economists and 63 non-academic economists. Some results of this survey such as an ambivalent position between Keynesian, Monetarist and Market Advocate and correlation of average opinion among economists are also compared with those of the Japanese and the U.S. samples, which were surveyed by Takase et al. (2000) with the same propositions. This is the first survey that covers academic and non-academic economists in Korea.

JEL Classification: A10, A11

Keywords: Korean economists, economic belief, Keynesian, Monetarist,

Market Advocate

\section{INTRODUCTION}

Economic beliefs clearly differ among economists. These differences reflect the motivation for academic research, where the economists have been trained, and the professionalism of these economists.

The objective of this paper is to examine the extent of agreement among Korean economists concerning 29 propositions. 1 This paper consists of five sections. In section II, the properties of the sample and a measure of consensus are introduced. Then degrees of consensus about positive versus normative statements and microeconomic versus macroeconomic propositions among the economists surveyed are investigated. In section III, the economists surveyed are iden-

Received for publication: March 14, 2001. Revision accepted: June 10, 2001.

* Department of Economics, University of Ulsan, Ulsan, Korea.

' This research which was supported by a grant from University of Ulsan(2000) was designed to extend a line of other researches (Kearl et al. (1979), Frey et al. (1984), Block and Walker (1988), Ricketts and Shoesmith (1990), and Coleman (1992), and Alston et al. (1992) in order to compare results across countries. 
tified as supporters of Keynesian, Monetarist, and Market Advocate according to their answers, and then the share of each school of thought is compared based upon these economists' educational backgrounds. The results of the Korean survey are compared with those of the Japanese and the US samples, which were surveyed by Takase et al. (2000) with the same propositions. The controversy about the role of the market system and the government intervention is also investigated in this section. In section IV, correlation coefficients of average opinion among economists are compared domestically and internationally based upon age groups and educational backgrounds. The survey results are summarized in the conclusion.

\section{THE SAMPLE AND ITS PROPERTIES}

This research was based upon two separate samples of academic and non-academic economists beliefs in Korea. The academic (non-academic) economists were defined as the economists working in academic (non-academic) institutions. Each sample was selected from the Member Directory of the Korean Economic Association published in 1993 by choosing every third name starting with the first person listed. The surveys were conducted from April 1998 to April 1999. The sample returned 167 questionnaires for academic economists and 63 for non-academic economists, a response rate of 33.6 and 30.0 percent respectively. ${ }^{2}$

Respondents were asked to indicate their educational backgrounds. While many Korean universities run extensive graduate programs, Korean economists extensively preferred to obtain their advanced training in the U.S. As shown in Chart 1, almost 59 percent of academic economists and 43 percent of non-academic economists have received graduate training at U.S institutions. According to the data from Takase et al. (2000), only 16 percent of the Japanese sample attended

Chart 1. Comparison of Graduate Training

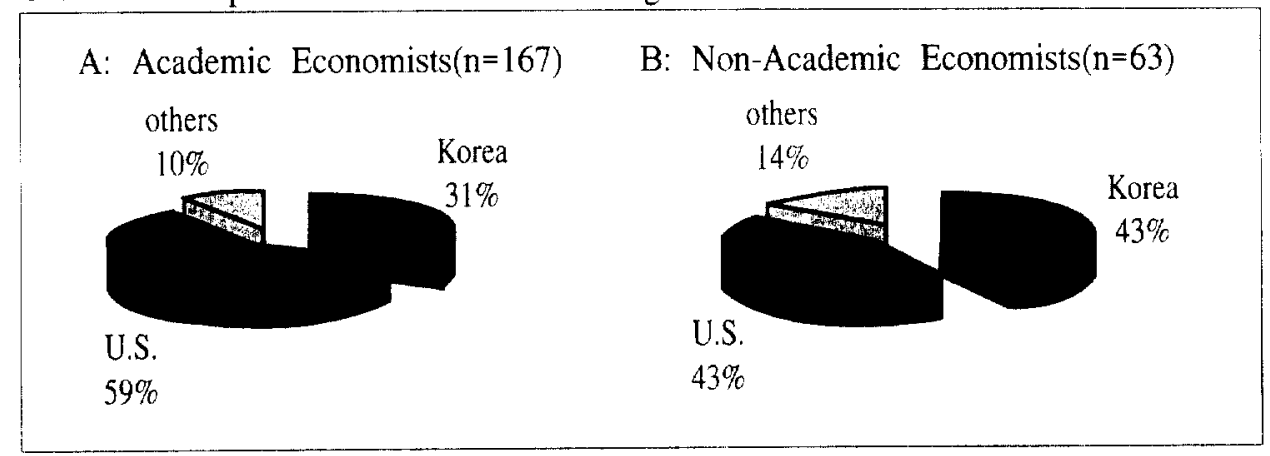

\footnotetext{
${ }^{2}$ This research was done as a part of Takase et al (2000) which research was financially supported by Japan Private School Promotion Foundation and Fukuoka University. The data for the Korean non-academic economists was newly collected and analyzed here and the data for Japan $(n=275)$ and the US $(n=487)$ survey used in this paper were from Takase et a.l (2000).
} 
U.S. graduate programs. The majority of Japanese economists trained in domestic institutions. The difference in educational background might result in different beliefs about how to assess, analyze and approach economic issues domestically and internationally.

\section{A Measure of Consensus: Relative Entropy ${ }^{3}$}

Respondents were asked to indicate their degree of agreement with an individual proposition using a three-point scale. Relative entropy is employed as a measure of consensus. Survey results, along with relative entropy indices and the mean value scale are reported in Table 1. According to the information theory, the relative entropy index ranges between 0 (perfect consensus) and 1 (non-consensus). It is important to note that the relative entropy index is nonlinear and, as a consequence, large changes in the distribution of responses result in small changes in entropy. Other surveys suggest that the value of the relative entropy index less than .7 indicate a substantial degree of consensus among respondents.

[Table 1] Ranks of Economic Propositions

\begin{tabular}{|c|c|c|c|c|c|c|c|}
\hline \multirow{2}{*}{ Macroeconomic Issues } & \multicolumn{4}{|c|}{ academic } & \multicolumn{3}{|c|}{ non-academic } \\
\hline & & $\%$ & mean & entropy & \& & mean & entropy \\
\hline \multicolumn{8}{|l|}{ Keynesian } \\
\hline 2. The goverment should be on employer of last resort and initiate a guaranteed job program. & $\begin{array}{l}1 \\
2 \\
3\end{array}$ & $\begin{array}{l}27.5 \\
40.7 \\
30.5\end{array}$ & 2,004 & 0.98584 & $\begin{array}{r}32,3 \\
38.7 \\
20\end{array}$ & 1.967 & 0.99343 \\
\hline 8. Fiscal policy has a significant stimulative impact on a less than fully employed economy. & $\frac{1}{3}$ & $\begin{array}{l}563 \\
353 \\
84\end{array}$ & 1.521 & 0.81837 & $\begin{array}{r}50.8 \\
41.3 \\
70\end{array}$ & 1.571 & 0.82814 \\
\hline 25. In the short nun, unempioyment can be reduced by increasing the rate of inflation. & $\begin{array}{l}3 \\
2 \\
3\end{array}$ & $\begin{array}{l}3.7 \\
34.7 \\
37.1 \\
26.9\end{array}$ & 1.896 & 099066 & $\begin{array}{l}113 \\
25.4 \\
333\end{array}$ & 1.92 & 0.98258 \\
\hline \multicolumn{8}{|l|}{ Monetarist } \\
\hline 3. The money supply is a mote important target than interest rates for monetory policy. & $\frac{1}{2}$ & $\begin{array}{l}37.7 \\
34.7 \\
26.9\end{array}$ & 1.878 & 0.99057 & $\begin{array}{r}14,3 \\
31 . ? \\
54\end{array}$ & 2.397 & 0.88753 \\
\hline 12. Inflation is primarily a monetary phenomenon. & $\frac{1}{3}$ & $\begin{array}{r}38.9 \\
43.1 \\
18\end{array}$ &. .791 & 0.94546 & $\begin{array}{l}28.6 \\
\$ 7.6 \\
23.8\end{array}$ & 1.952 & 0,95848 \\
\hline 16. The central bank should be instructed to increase the money supply at a fixed rate. & $i$ & $\begin{array}{l}2] \\
43.7 \\
34.1\end{array}$ & 2.107 & 0.96155 & $\begin{array}{l}9.5 \\
30.2 \\
60.3\end{array}$ & 2.508 & 0.81032 \\
\hline 20. The central hank has the capacliy to achieve a constant ate of growth of the money supply at a fixed rate. & $\frac{1}{2}$ & $\begin{array}{l}33.5 \\
33.5 \\
31.1\end{array}$ & 1.938 & 0.99759 & $\begin{array}{l}30.2 \\
28.6 \\
41 ., 3\end{array}$ & 2.113 & 0.98744 \\
\hline
\end{tabular}

${ }^{3}$ The relative entropy score, $e$, is $e=-\frac{\sum_{i=1}^{n} P_{i} \ln P_{i}}{\ln n}$, where $P_{i}$ represents the proportion of the response category, $i$, and $n$ represents the number of response categories. The reported entropy statistics in Table 1 are calculated as follows. Suppose that the response frequency of each category are $33.3 \%(70 \%), 33.3 \%(20 \%)$ and $33.3 \%(10 \%)$, the entropy statistics is calculated $0.999(0.359)$ by the formula above. Several definitions of relative entropy are possible depending on how the response categories are counted. Here only one definition of relative entropy is used, which excludes no answers and allows for three response categories only because 'no answer' has at most $3 \%$ share for two questions but less than $1 \%$ for the rest of questions. 
Market Advocates, Goverment Intervention, Deregulation

5. Flexible exchange rates offer on efficient intermational monetary arangement.

7. The government should index the income tax rate structure for inflation.

9. The distribution of income should be more equal.

11. Antitust laws sbould be used vigorously to reduce monopoly power from its current level.

13. The government should restucture the welfare system along lines of a "negative income ax."

15. A ceiling on rents reduces the quantity and quality of housing available.

17. Effuent taxes represent a better approach to pollution control than imposition of pollution ceilings.

18. The govenment should issue an inflation indexed security.

19. The level at government spending should be reduced (distegarding expenditures for stabilization).

21. Reduring the influence of regulatory authorilies (e.p., in air traffic) would imporove the efficiency of the ecconomy

2. The government budget should be balanced over the business cycle rather than yearly.

24. The redistribution of income in the developed industrial nations is a legitimate role for government.

26. Consemer protection laws generally reduce economic efficiency.

Internalization

1. Tariffs and impor quatas reduce general ecconomic welfare.

28. Liberalization in intemational trade and investment should be accelerated.

29. Regional economic integration is an effective mexure for liberalization in intemational trade and investment.

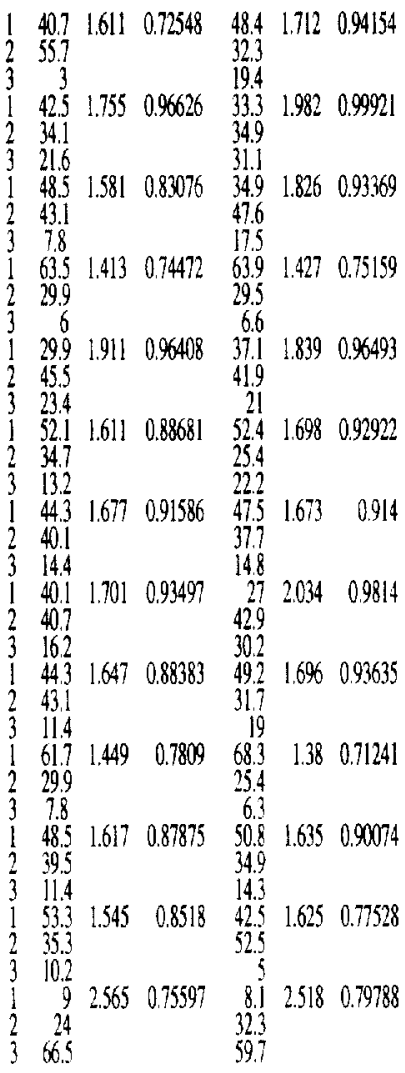

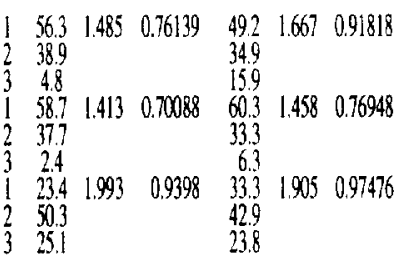

etc.

6. A minimum wage increases unemployment among young and unskilled workers.

10. National defense expenditures should be reduced from the present level.

14. Wage-price controls should be used to control inflation.

27. Reduction in trade union power

4. Cash payment are superior to tansfer-in.kind.

23. The fundamental calse of the rise in oil prices that occurred in the wake of the laapi invasion of Kuwait is the monopoly power of the large oil companies.

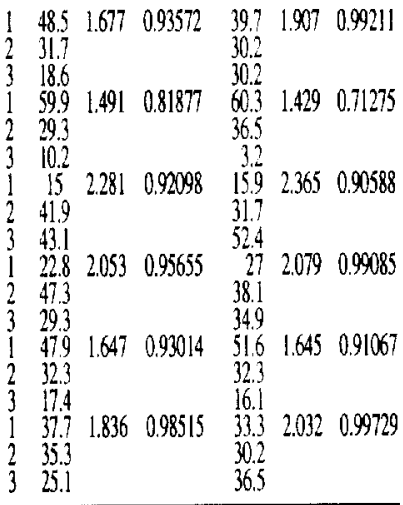


[Table 2] Mean and Standard Deviation, 29 propositions

\begin{tabular}{clcc}
\hline Country & & Average & Standard Deviation \\
\hline \multirow{2}{*}{ Korea } & Acadmic & 0.869 & 0.091 \\
& Non-academic & 0.886 & 0.091 \\
\hline
\end{tabular}

The means and standard deviations for each entry measure are shown in Table 2. As shown, there was no significant difference in average score and deviations between academic and non-academic economists in Korea: this result implied that each group had a similar opinion about the survey propositions.

\section{The Degree of Consensus: Positive Statements versus Normative Statements}

This section first examines whether there is a difference in the degree of consensus with respect to positive and normative statements and microeconomic and macroeconomic propositions. ${ }^{4}$ We tested a null hypothesis that the degrees of consensus were equal between them. The results of the test are illustrated in Table 3. Table 3-a shows that each group had a higher degree of consensus (lower average entropy score) on normative statements than positive statements. Also both the academic and non-academic economists had a higher degree of consensus on microeconomic propositions than macroeconomic propositions even though the differences are not statistically significant (see, Table 3-b).

[Table 3-a] Positive statements versus normative statements

\begin{tabular}{lcccc}
\hline & Positive & Normative & F-value & P-value \\
\hline Academic & 0.900 & 0.895 & 0.840 & 0.390 \\
Non-academic & 0.932 & 0.889 & 0.169 & 0.006 \\
\hline
\end{tabular}

[Table 3-b] Microeconomics versus macroeconomics proposition

\begin{tabular}{lcccc}
\hline & Microeconomics & Macroeconomics & F-value & P-value \\
\hline Academic & 0.826 & 0.956 & 2.531 & 0.091 \\
Non-academic & 0.870 & 0.939 & 1.666 & 0.229 \\
\hline
\end{tabular}

\footnotetext{
${ }^{4}$ For the classification of propositions as positive or normative, we follow the previously cited surveys, which were indicated in Footnote 1. Questions 1, 3, 4, 5, 6, 8, 12, 15, 17, 20, and 25 are classified as positive; questions $2,7,11,13,16,18,21,26$, and 27 are normative; questions $1,4,5,6,8,11,15,17,21$, and 26 are mictoeconomic propositions; questions $2,3,7,8,12$, $13,16,18,20$ and 25 are macroeconomic propositions.
} 


\section{RESPONSES TO ECONOMIC PROPOSITIONS}

\section{Keynesians, Monetarists, and Market Advocates}

This section seeks to identify economists as Keynesians, Monetarists, and Market Advocates. Following Coleman (1992), respondents who generally agree or agree with provisions to propositions 2, 8, and 25 are classified as Keynesian economists. Respondents who generally agree or agree with provisions to questions 3, 12, and 16 are classified as Monetarists. Market advocates are considered as respondents who generally agree or agree with provisions to questions 1,6 , and 15 , and who generally disagree with question 14 . The domestic share of each school of thought is shown in Table 4. In the Table, Korea-Korea (and Korea-U.S.) represents a group of economists who live in Korea and obtained their academic degrees in Korea (and the U.S.).

There are three propositions related to Keynesian views. 68.2 percent (academic) and 71 percent (non-academic) of economists surveyed were in favor of (either agreeing or agreeing with provision) the proposition (2) that the government should be an employer of last resort and initiate guaranteed job program. Reviewing proposition 8 regarding which fiscal policy does stimulate the economy, strong support was found with 92.6 percent (academic) and 92.1 percent (non-academic) of economists either agreeing or agreeing with provision to this proposition. 61.8 percent (academic) and 66.7 percent (non-academic) of economists agreed or agreed with provision 25 that unemployment can be reduced by the increasing rate of inflation in the short run. Accordingly, both the Korean academic and non-academic economists strongly supported the Keynesian view.

The questionnaires also queried three propositions related to Monetarist views. The academic economists generally believed $(72.4 \%)$ that the money supply is an important target (prop.3) but only 46 percent of non-academic economists agreed with the proposition. There also existed strong support for the proposition (12) that inflation is primarily a monetary phenomenon. In contrast, the non-academic economists were opposed to proposition 16 with regard to the establishment of a money supply rule. 60.3 percent of the non-academic economists and 34.1 percent of the academic economists disagreed with proposition 16 . However, over 60 percent of the U.S. trained Korean academic economists answered in favor of the establishment of a money supply rule. This implies that the U.S. trained academic economists strongly tended to believe in Monetarist views.

With regard to the proposition that the central bank has the capacity to achieve a constant rate of growth of the money supply at a fixed rate (prop 20 ), over 30 percent of both the academic and non-academic economists surveyed disagreed with this proposition. In brief, there was dubious belief in the capacity of the central bank and the consensus regarding proposition 20 was very low $(0.987)$. 
[Table 4] Keynesian, Monetarist and Advocate Views

\begin{tabular}{l|c|c|c|c|c|c}
\hline & Keynesian & Monetarist & $\begin{array}{c}\text { Keynesian \& } \\
\text { Monetarist }\end{array}$ & $\begin{array}{c}\text { Market } \\
\text { Advocate }\end{array}$ & $\begin{array}{c}\text { Keynesian \& } \\
\text { Market } \\
\text { Advocate }\end{array}$ & $\begin{array}{c}\text { Monetarist \& } \\
\text { Market } \\
\text { Advocate }\end{array}$ \\
\hline Academic & $49.10 \%$ & $47.31 \%$ & $29.34 \%$ & $31.74 \%$ & $10.18 \%$ & $14.97 \%$ \\
\hline Korea- Korea & $59.62 \%$ & $53.87 \%$ & $42.31 \%$ & $15.38 \%$ & $3.85 \%$ & $5.77 \%$ \\
Korea-US & $39.39 \%$ & $44.44 \%$ & $22.22 \%$ & $41.41 \%$ & $12.12 \%$ & $20.20 \%$ \\
\hline Non Academic & $46.03 \%$ & $22.22 \%$ & $12.70 \%$ & $22.22 \%$ & $14.29 \%$ & $6.39 \%$ \\
\hline Korea-Korea & $\mathbf{6 2 . 9 6 \%}$ & $14.81 \%$ & $14.81 \%$ & $11.11 \%$ & $11.11 \%$ & 0 \\
Korea-US & $\mathbf{2 9 . 6 3 \%}$ & $33.33 \%$ & $14.81 \%$ & $40.74 \%$ & $22.22 \%$ & $14.81 \%$ \\
\hline Total & $\mathbf{4 8 . 2 6 \%}$ & $\mathbf{4 0 . 4 3 \%}$ & $\mathbf{2 4 . 7 8 \%}$ & $\mathbf{4 0 . 1 1 \%}$ & $\mathbf{1 5 . 5 7 \%}$ & $17.37 \%$ \\
\hline
\end{tabular}

The number of economists who supported Keynesian, Monetarist, and both of them are presented in Table 4 . It shows that 48.3 percent (total) and 40.4 percent (total) of economists surveyed held the Keynesian and Monetarist views respectively. Also 29.34 percent (academic) and 12.70 percent (non-academic) of economists surveyed held both Keynesian and Monetarist views. Especially the academic economists who have been trained domestically were inclined to hold both positions $(42.3 \%) .5$

The number of economists who held Market Advocate view, both Keynesian and Market Advocate views, and both Monetarists and Market Advocate views are indicated in Table 4. The share of the Korea-US academic economists who supported Market Advocates was more than two times that of the Korea-Korea academic economists. The non-academic economists (22.2\%) who presumably dealt with real economic issues more frequently were less likely to support market mechanism than the academic economists $(31.7 \%)$.

\section{The Role of the Market System and the Government}

The degree of confidence in markets was mixed depending on the propositions proposed but generally high levels of support were found apparent. With the number of the propositions related to regulation, there was a comfortable consensus for economists in Korea. 91.6 percent (academic) and 93.7 percent (non-academic) of economists agreed or agreed with provision with the proposition (21) that

\footnotetext{
5 According to Takase et al. (2000), 37.1 percent and 32.7 percent (24.6 and 34.6 percent) of the Japanese (U.S.) economists surveyed believed in Keynesian and Monetarist views respectively. Only 25 percent (4.7 percent) of the Japanese sample (U.S.) held both Keynesian and Monetarist views. These results showed that Keynesian and Monetarist views were relatively less distinct in Korea. In addition, the Market Advocates were majority in the U.S. economists and most of Monetarists in the U.S. were also Market Advocates but less than half of the Monetarists were Market Advocates in Korea and Japan.
} 
reducing the influence of regulatory authorities would improve the efficiency of the economy. Similarly, more than half of the Korean economists supported the vigorous reliance of anti-trust legislation to reduce the current level of monopoly power (prop 11). The consensus regarding the proposition 11 was very high $(0.75)$.

84.4 percent (academic) and 85.2 percent (non-academic) of economists agreed or agreed with provision with the proposition (17) that effluent taxes represent a better approach to pollution control than imposition of pollution ceilings. This trend is similar to the score regarding proposition 15 that a ceiling on rents reduces the quantity and quality of housing available. Only the question on consumer protection laws (prop. 26) occasioned significant dissent. Based upon the answers to questions 11 and 17, the Korean sample would appear to support the position that the failure of the market in Korea was significant. Moreover, Korean economists supported the view that consumer protection laws increase efficiency. These results imply that strong support exists for the provision upholding the role of the market system.

One distinct opinion among economists was the role that the government should play regarding more equal income distribution. The majority of the Korean economists surveyed accepted the proposition (9) that redistribution of income was a legitimate task for modern governments. This outcome was compatible with the opinion held by 91.6 percent (academic) and 82.5 percent (non-academic) of economists that distribution of income should be equal. These results reflect the fact that income distribution is less equal in Korea. Also over 75.5 percent (academic) and 79 percent (non-academic) of economists were in favor of a negative income tax (prop.13) and inflation indexed security (prop.18). With regard to the role of the government, the Korean economists were, as stated above, in favor of the government intervention for income distribution. This position was closely related to the proposition that the government should index the income tax rate structure for inflation (prop 7). 76.6 percent (academic) and 68.2 percent (non-academic) of economists were in favor of an indexed income tax rate.

Accordingly, the Korean economists had theoretically broad views with regard to the role of the market and the government, this broad view was similarly found in the discussion of the propositions of Keynesian, Monetarist, and Market Advocates.

\section{Other Issues}

The proposition related to tariffs generated very high agreement. Nearly 95.2 percent (academic) and 84.1 percent (non-academic) of economists agreed or agreed with provision with the proposition (1) that tariffs and import quotas reduce general economic welfare. This conveyed an impression of a high degree of consensus among the economists about the efficacy of freer trading arrangements in improving general economic welfare. With regard to the liberalization of trade and international investment (prop.28), high levels of support were 
found. Nearly 97 percent (academic) and 94 percent (non-academic) of economists generally agreed with the proposition that liberalization in international trade and investment should be accelerated (prop.28). In addition, in response to the question on regional integration, 75 percent (academic) and 76 percent (non-academic) economists surveyed generally agreed with the notion that regional economic integration is an effective measure for liberalization in international trade and investment (prop. 29). A relatively high level of support for questions of liberalization as well as that of the regional integration indicated that Korean economists were likely disposed to openness.

The proposition related to labor union activities, 71.1 percent (academic) and 65.1 percent (non-academic) of economists agreed or agreed with provision with the proposition, with a low consensus, that the economic power of labor unions should be significantly curtailed (prop.27). The Korean economists surveyed thought that the power of the unions was still a problem in Korea. ${ }^{6}$ As mentioned, among the Korean respondents, strong support was found for the proposition that the government should be an employer of last resort and initiator of a guaranteed job program (prop. 2). The Korean respondents tended to put more value on the role of government with regard to labor issues. In addition, the majority of the Korean economists disagreed with the proposition (14) that wage-price controls should be used to control inflation.

This survey included propositions related to what might define the proper level of national defense expenditures (prop.10). Nearly 89.2 percent (academic) and 96.8 percent (non-academic) of economists were in favor of reductions in national defense expenditures. In regard to oil price, 73 percent (academic) and 63.5 percent (non-academic) of economists believed that the rise of oil prices was caused by the monopoly power of the large oil companies. The remaining 4 propositions fall into the qualified support range. In descending order of support are: Cash payment is superior to transfer-in-kind (prop.4). The level of government spending should be reduced (disregarding expenditures for stabilization)(prop 19). Flexible exchange rates offer an efficient international monetary arrangement (prop 5). A minimum wage increases unemployment among young and unskilled workers (prop 6).

\section{CORRELATION OF AVERAGE OPINION}

After obtaining the average score for each proposition in each group, correlation coefficients were calculated and summarized in Tables 5-a and 5-b. Table 5 -a shows the correlation coefficients of the average opinion between the age groups of the Korean economists. Table 5-b denotes economists in their $30 \mathrm{~s}$, $40 \mathrm{~s}, 50 \mathrm{~s}$, and $60 \mathrm{~s}$.

\footnotetext{
${ }^{6}$ The Japanese respondents $(\mathrm{n}=275)$ were significantly opposed. The majority of respondent $(64$ percent) opposed any significant curtailment of union power.
} 
Table 5-a indicates that Korea has a relatively higher value of correlation coefficients (0.78) with Japan than with the U.S $(0.60)$. This indicates that the Korean economists tended to hold for more similar views with the Japanese economists than the U.S. economists. Surprisingly, the Korea-U.S. economists who obtained their academic degrees in the U.S. had the higher correlation coefficient with the Japanese economists than the U.S. economists. The similar belief on economic issues between the Korean and Japanese economists could be interpreted that economists' belief have been affected not only by their educational backgrounds but also by the cultural, social, economic and historical backgrounds of the countries surveyed. The government led economic structure of these two countries might lead to the similar belief on economic issues compared with the market-oriented economy of the U.S. Among groups, the Korean economists who were in their $60 \mathrm{~s}$ had the lowest correlation of opinion-that is, the economists in this age group tended to have relatively different opinions from the economists in the other age groups. This phenomenon also appears in Table 5-b in which academic economists in their 40s and 50s and non-academic economists in their $30 \mathrm{~s}$ and $40 \mathrm{~s}$ had relatively higher average values of correlation coefficients. As in Table 5-a, the Korea-U.S. economists had an even higher correlation of opinions with the other groups.

[Table 5.a] International Comparison of Correlation of Average Opinion

\begin{tabular}{l|c|c|c|c|c|c|c}
\hline & Korea & Korea 30s & Korea 40s & Korea 50s & Korea 60s & Korea-Korea & Korea-US \\
\hline Japan & 0.779 & 0.768 & 0.777 & 0.724 & 0.376 & 0.591 & 0.811 \\
US & 0.598 & 0.471 & 0.685 & 0.504 & 0.130 & 0.393 & 0.679 \\
\hline
\end{tabular}

The data for Japan and the U.S. are from Takase et al. (2000)

[Table 5.b] Correlation of Average Opinion of Korean Economists

\begin{tabular}{c|c|ccccccc}
\hline & & \multicolumn{7}{|c}{ Academic } \\
\hline & & total & $30 \mathrm{~s}$ & $40 \mathrm{~s}$ & $50 \mathrm{~s}$ & $60 \mathrm{~s}$ & $\begin{array}{c}\text { Korea- } \\
\text { Korea }\end{array}$ & $\begin{array}{c}\text { Korea- } \\
\text { U.S. }\end{array}$ \\
\cline { 2 - 9 } Non- & total & 0.885 & 0.850 & 0.855 & 0.760 & 0.074 & 0.770 & 0.819 \\
Academic & $30 \mathrm{~s}$ & 0.785 & 0.822 & 0.724 & 0.659 & 0.066 & 0.679 & 0.741 \\
& $40 \mathrm{~s}$ & 0.855 & 0.794 & 0.845 & 0.724 & 0.064 & 0.696 & 0.835 \\
& $50 \mathrm{~s}$ & 0.873 & 0.831 & 0.834 & 0.784 & 0.040 & 0.801 & 0.756 \\
& $60 \mathrm{~s}$ & 0.567 & 0.568 & 0.516 & 0.511 & 0.193 & 0.638 & 0.399 \\
& Korea-Korea & 0.761 & 0.782 & 0.717 & 0.615 & 0.116 & 0.801 & 0.559 \\
& Korea-U.S. & 0.849 & 0.787 & 0.835 & 0.736 & 0.052 & 0.651 & 0.877 \\
\hline
\end{tabular}


[Table 6] Ranks of Consensus of Proposition

\begin{tabular}{|c|c|c|c|c|}
\hline & $\begin{array}{c}\text { Korea } \\
\text { Academic }\end{array}$ & $\begin{array}{c}\text { Korea } \\
\text { Non Academic }\end{array}$ & $\begin{array}{c}\text { Japan } \\
\text { Academic }\end{array}$ & $\begin{array}{l}\text { The US } \\
\text { Academic }\end{array}$ \\
\hline \multirow[t]{3}{*}{$\begin{array}{l}\text { Highest } \\
\text { consensus }\end{array}$} & $\begin{array}{l}\text { 28. Trade liberalization } \\
(0.701)\end{array}$ & $\begin{array}{l}\text { 21. Reducing regulatory } \\
\text { authorities }(0.712)\end{array}$ & $\begin{array}{l}\text { 27. Reduction in labor } \\
\text { union power }(0.736)\end{array}$ & $\begin{array}{l}\text { 14. Wage price control } \\
\qquad(0.228)\end{array}$ \\
\hline & $\begin{array}{l}\text { 5. Flexible exchange } \\
\text { rates }(0.725)\end{array}$ & $\begin{array}{c}\text { 10. National defense } \\
(0.713)\end{array}$ & $\begin{array}{r}\text { 4. Cash payment } \\
(0.764)\end{array}$ & $\begin{array}{l}\text { 15. A Ceiling on rent } \\
(0.541)\end{array}$ \\
\hline & $\begin{array}{l}\text { 11. Anti-trust law } \\
(0.745)\end{array}$ & $\begin{array}{l}\text { 11. Anti-trust law } \\
(0.752)\end{array}$ & $\begin{array}{l}\text { 5. Flexible exchange } \\
\text { rates }(0.854)\end{array}$ & $\begin{array}{l}\text { 1. Tariff and import } \\
\text { quota }(0.552)\end{array}$ \\
\hline \multirow[t]{3}{*}{$\begin{array}{l}\text { Lowest } \\
\text { consensus }\end{array}$} & $\begin{array}{l}\text { 20. Fixed rate of Money } \\
\text { supply }(0.998)\end{array}$ & $\begin{array}{c}\text { 7. Income tax rate } \\
(0.999)\end{array}$ & $\begin{array}{c}\text { 6. Minimum wage } \\
(0.994)\end{array}$ & $\begin{array}{l}\text { 9. Distribution of income } \\
(0.997)\end{array}$ \\
\hline & $\begin{array}{l}\text { 1. Tariff and import } \\
\text { quota }(0.986)\end{array}$ & $\begin{array}{l}\text { 23. Monopoly power in } \\
\text { oil company ( } 0.997)\end{array}$ & $\begin{array}{l}\text { 25. Phillips curve } \\
(0.993)\end{array}$ & $\begin{array}{l}\text { 11. Anti-trust law } \\
(0996)\end{array}$ \\
\hline & $\begin{array}{l}\text { 23. Monopoly powet in } \\
\text { oil company ( } 0.986)\end{array}$ & $\begin{array}{l}\text { 1. Tariff and import } \\
\text { quota }(0.993)\end{array}$ & $\begin{array}{l}\text { 3. Money supply target } \\
(0.99)\end{array}$ & $\begin{array}{l}\text { 25. Phillips curve } \\
(0.992)\end{array}$ \\
\hline
\end{tabular}

Number in the column indicates the number of questionnaires in the survey. ()- entropy value. The data for Japan and the U.S. are from Takase et al. (2000)

Table 6 shows the highest rank of consensus in each country. The differences in ranks among countries are reflected the differences in the cultural, social, economic, and historical backgrounds of these countries which have already mentioned.

\section{CONCLUSION}

This paper has investigated academic and non-academic economists' beliefs about economic issues. The results indicate that there was no significant difference in economists' consensus between positive and normative statements (Table 3). As for the difference in consensus between microeconomic and macroeconomic propositions, the results showed that microeconomic propositions had a higher degree of consensus (a lower average entropy score) than macroeconomic propositions (Table 4). In addition, the survey showed that the academic economists were more Keynesian and Monetarists than were the non-academic economists. Especially, the numbers of the academic economists who strongly supported Monetarist view, and who held both Keynesian and Monetarist views were more than two times than the non-academic economists. Especially the academic economists who have been trained domestically were inclined to hold an ambivalent position (42.3\%). Internationally, such an ambivalent position was greater for the Korean sample than the Japanese and the U.S. samples. This result might be correlated with the extent of ambivalent economic beliefs on the 
proposition surveyed. Such an ambivalent opinion similarly appeared in the discussion of the role of the government and the market system. We also found that the Korean economists were more in favor of openness to trade and less generosity toward labor union. As for correlation of average opinions among different countries economists, Japan and Korea had generally high correlation each other. There was a tendency for the economists who had been educated in the U.S. to have a get higher correlation than domestically educated (Table 5).

Generally the ambivalence in economics appears when economists are less likely to focus on abstract economic issues. This phenomenon can be explained by the different market conditions faced by economists. Korea has its own separate market for economists, which is smaller and less competitive than in Japan and the U.S. Thus, the incentives to perform in academic research are relatively lower. Accordingly, the economists are more concerned with practical issues so their opinions tend to be theoretically broad and institutionally specialized. According to this analysis, the broad opinions in Korea are the inevitable consequence of its own research market condition and cannot be reversed by wishful thinking. The extent of broadness on economic views among economists was serious. 


\section{REFERENCES}

Alston, Richard M., J. R. Kearl, Michael B. Vaughan, "Is There a Consensus Among Economists in the 1990's?" American Economic Review, May 1992 (Papers and Proceedings), 82, 203-209.

Block, W. and M. Walker, "Entropy in the Canadian Economic Profession: Sampling Consensus on the Major Issues," Canadian Public Policy, 1988, $14,137-150$.

Coleman, W., "Concord and Discord amongst New Zealand Economists: The Results of an Opinion Survey," New Zealand Economic Papers, 1992, 26, 47-81.

Frey, Bruno, Werner W. Pommerehne, Friedrich Schneider, and Guy Gilbert, "Consensus and Dissension Among Economists: An Empirical Inquiry," American Economic Review, December 1984, 74, 986--994.

Kearl, J. R., Clayne L. Pope, Gordon C. Whiting, and Larry T. Wimmer, "A Confusion of Economists?" American Economic Review, May 1979, 69, 28-37.

Ricketts, Martin, and Edward Shoesmith, British Economic Opinion: A Survey of a Thousand Economists. London: Institute of Economic Affairs, 1990. "British Economic Opinion: Positive Science or Normative Judgment? American Economic Review, May 1992 (Papers and Proceedings), 82, 210-216.

Takase, Mitsuo, JM Kang, S.Martin, Jae Ho Cho, M. MacAleer, B. Nahata and L. Oxley, "Economists' Beliefs About Economic Issues: A Comparison of 10 countries," Fukuoka University Review of Economics, Vol. 44, March 2000. 